\section{Comparative Research of the Thin Transverse Sectional Anatomy and the Multislice Spiral CT on Pterygopalatine Fossa}

\section{Multislays Spiral Tomografi ile Pterigopalatin Fossanın İnce Transverse Kesitsel Anatomisinin Karșılaștırmalı Araștırılması}

\begin{abstract}
AIM: To explore a method to obtain sub-millimeter data of the thin transverse section of the pterygopalatine fossa (PPF), and to study the thin transverse sectional anatomy of the adult pterygopalatine fossa and its communicating structure for providing anatomic gist for the imaging diagnosis and minimal invasive operation when PPF diseased.

MATERIAL and METHODS: Two heads of adult cadaver without macroscopic trauma (four sides of PPF) were selected to observe. Images of $0.6 \mathrm{~mm}$-thick multi-planar construction (MPR) were obtained with multislice spiral CT (MSCT) based on the superior orbitomeatal line. Then, the specimens were sliced into $0.1 \mathrm{~mm}$ serial section on the transverse plane with the computerized milling machine, the figures were taken with digital camera and the sectional data were stored in the computer. Lastly, the thin transversal section of PPF was investigated and compared with multislice spiral CT images acquired by MPR technique to explore and discuss the anatomy of the thin transverse section of the internal structure of PPF.

RESULTS: PPF was divided into four portions: infrapterygopalatine portion, pterygopalatine ganglionic one, suprapterygopalatine one and roof of PPF according to the structural characteristics of the transverse section of PPF. The infrapterygopalatine portion communicated laterally with the infratemporal fossa through the pterygomaxillary fissure and communicated downwards with the oral cavity via palatine greater and lesser canals. The pterygopalatine ganglion was shown clearly in the pterygopalatine ganglionic portion, and its dimensions were $3.91 \times 1.92 \mathrm{~mm}$ at the best layer. In the suprapterygopalatine portion, the sphenopalatine foramen and artery were obviously shown on the medial wall, while the palatovaginal canal and artery, the pterygoid canal and artery, and the foramen rotundum and maxillary nerve were shown from the inferiomedial to laterosuperior on the posterior wall. The vomerovaginal canal and artery were located at the slightly superior portion of the medial side of the palatovaginal canal.

CONCLUSION: Figures of thin transverse section and multislice spiral CT have highly consistency for the display of PPF. Both of them can correctly identify the micro-structure, the complex relationship of the connectivity and the spatial localization in the narrow space of PPF. It can provide reference gist for the imaging diagnosis and minimal invasive operation.
\end{abstract}

KEYWORDS: Pterygopalatine fossa, Laminoanatomy, Computerized cryomilling technique, Multislice spiral CT

\section{ÖZ}

AMAÇ: Bu çalışmada, piterigopalatin fossayı tutan hastalıklarda minimal invaziv girişimleri sağlayabilecek, piterigopalatin fossanın submilimetrik verilerini elde edebilecek bir yöntem ve piterigopalatin fossanın anatomik bağlantıları araştırılmıştır.

\section{Cheng-Chun CHEN $^{1,8}$ \\ Zhong-Xiao CHEN $^{2}$ \\ Xin-Dong YANG ${ }^{3}$ \\ Jian-Wu ZHENG ${ }^{4}$ \\ Zhen-Ping LI5 \\ Fei HUANG ${ }^{6}$ \\ Fan-Zhen KONG7 \\ Chuan-sen ZHANG ${ }^{8}$ \\ 1,2,3 Wenzhou Medical College, Department of Human Anatomy, Wenzhou, Republic of China \\ 5 Shandong University, School of Medicine, Department of Human Anatomy, Jinan, Republic of China \\ 6,7 Binzhou Medical College, Department of Human Anatomy, Yantai, Republic of China \\ 8 The Second Military Medical University,Department of Human Anatomy,Shanghai, Republic of China}

Received : 06.11.2009

Accepted : 10.12.2009

Correspondence address: Chuan-sen ZHANG

E-mail : neuroman@163.com Fei HUANG

E-mail : hfei22518@163.com 
YÖNTEM ve GEREÇ: Kafa travması almamış iki yetişkin kadavra kafası bu incelemede kullanılmıştır. Superior orbitometal hat nirengi noktası olmak üzere $0.6 \mathrm{~mm}$ kalınlı̆̆ında kesitler multi-planar multislays spiral bilgisayarlı tomografi kullanılarak elde edilmiştir. Ardından, bilgisayarlı doku kesme makinesi kullanılarak anatomik örnekler $0.1 \mathrm{~mm}$ kalınlığında doku örnekleri haline getirilmiştir. Bu örnekler, digital kamera kullanılarak görüntülenmiş ve veriler bilgisayarda depolanmıştır. Son olarak, pterigopalatine fossanın elde edilen ince doku kesit örnekleri MPR teknikleri ile elde edilen bilgisayarlı tomografi görüntü örnekleri ile karşılaştırılarak incelenmiştir.

BULGULAR: Piterigopalatine fossa transverse kesitlere göre dört bölüme ayrilır: İnfrapterigopalatin bölüm, ganglionik pterigopalatin bölüm, suprapiterigopalatin bölüm ve piterigopalatin fossanın çatısı. İnfrapiterigopalatin bölümü pterigogomaxillar fissure yolu ile lateralden infratemporal fossa ile; alt kısımda ise küçük ve büyük palatin kanallar yolu ile ağız boşluğu ile ilişkilidir. Piterigopalatin ganglion piterigopalatin ganglionik bölümünde yeralır; bu bölümün boyutları 3.91x1.92 mm'dir. Suprapiterigopalatine bölümünde sfenopalatine foramen ve arter yer alır. Medial yüzde palatovajinal kanal ve arter, piterigoid arter ve piterigoid kanal görülür. Foramen rotundum ve maksiler sinir posterior duvarın alt-iç üst-dış kısmında yer alır. Vomerovajinal kanal ve arter palatovajinal kanalın iç yüzünde yer alır.

SONUÇ: Multislays spiral bilgisayarlı tomografi ile görüntüleme piterigopalatine fossanın görüntülenmesini etkili bir şekilde yapar. Bu yöntem ile piterigopalatine fossanın mikro yapısı ve iç bağlantı ve ilişkileri gösterilebilmektedir. Bu yöntem minimal invaziv girişimler için referans olabilecek tanısal görüntüleme yapılabilmesine imkan sağlamaktadır.

ANAHTAR SÖZCÜKLER: Bilgisayarlı kriyomilling teknik, Laminoanatomi, Multislays spiral görüntüleme, Pterigopalatin fossa

\section{INTRODUCTION}

The shape of the pterygopalatine fossa (PPF) seems as an inversed pyramidal structure (2). Its space is narrow and small, but the structure is complicated. The communication and content are very intricacy. The contiguous relation is closely correlated to the maxillary, sphenoidal and ethmoidal sinuses. PPF communicates with nasopharyngeal, nasal, oral cavity, orbital apex, infratemporal fossa, middle cranial fossa and foramen lacerum. Its correlation is very complex (3, 4). Many diseases adjacent to the PPF all can spread and diffuse to PPF. Its clinical significance is very important. CT anatomy of pterygo- palatine fossa and its communications reported by Erdogen N, Unur E, et al. (1, 5-7). But the research on laminoanatomy combined with imaging anatomy is rare. However, the comparative research on the thin transverse laminoanatomy combined with multislice spiral CT has not been reported in literatures, especially the communicated structure of the posterior wall of PPF, such as the foramen rotundum, pterygoid canal, palatovaginal canal and its relation of the spatial localization was more rarely, and study on the vomerovaginal canal has not been reported in literatures. In our study, the thin transverse sectional laminoanatomy of the boundary, content, communication and its spatial localization of PPF were comparatively studied using thin transverse section laminoanatomy combined with multislice spiral CT. To provide reference for the imaging diagnosis and surgical minimal invasive operation, it was suggested that the transverse section of PPF was divided into four portions.

\section{MATERIAL and METHODS}

Acquisition of images of multislice spiral CT

Specimens were scanned with a SOMATOM sensation cardiac 64 slices high solution spiral CT made by SIEMENS, Germany. The scanning basic line was the superior orbitomeatal line. The scanning range was from the level of the hard palate to the maxillary sinus. The scanning parameters of the same nature in every direction were adopted (64 layer CT, matrix 512 x 512, FOV $310 \mathrm{~mm}$, collimation 0.6-mm, screw-pitch 1.0). The original data of 0.6$\mathrm{mm}$-thick was obtained for the reconstruction of CT image in the later stage and for the contrast observation on the 0.1 -mm-thick transverse section image of the specimens.

Acquisition of data of the thin transverse sectional slice

After the specimen was scanned with multislice spiral CT, they were embedded with gelatin and frozen in profound hypothermia, the frozen specimens were milled based on the superior orbitmeatal line with SKC-500 type computerized milling machine which was designed and made in Jinan First Machine Tool Factory, its milling precision was $0.001 \mathrm{~mm}$ (its computerized system and cutting tool were produced by Germany). The specimen was taken with a Canon EOS 20D digital camera, its 
resolution power was 8.2 millions pixels. The data were stored in the Dell brand computer with the computer software of Windows XP professional edition. The thickness of the serial transverse section of the head was $0.1 \mathrm{~mm}$. The file of the image taken was RAW format. The dimension of the image was $3504 \times 2336$. The anatomical data of the thin transverse section was obtained through backup of original data.

Contrast between the thin transverse section of PPF and images of multislice spiral CT.

i. Management of the images of the sectional specimen: The sectional anatomical images of 0.1 mm-thin PPF specimen through frozen milling were firstly transformed into JPG format and stored. Then, make the color of images, contrast, legibility and the background approach to the best level through a series of processes, such as management with Photoshop, adjustment of gray scale, strengthening of image, sharpening of margin, adjustment of coordinate and extraction of the boundary. Lastly, the images were preserved for the future use and precisely contrasted with the images of MSCT.

ii. Management of images of multislice spiral CT: The original images of 0.6 -mm-thick in each layer were reconstructed in $0.4 \mathrm{~mm}$ interval to axial images using bone algorithm. These images were managed and reconstructed in multislice in WIZARD imaging workstation. The image of sectional specimen was regarded as a standard and both of them were matched. CT original image of unmatched to the sectional image were adjusted with pleiotropia MPR adjusting technique to complete match.

iii. Comparative investigation: Images of the sectional specimen were contrasted with multislice spiral CT images and the anatomical structure of the transverse section of the PPF was observed layer by layer.

\section{RESULTS}

PPF appeared from the hard palate and disappeared at the maxillary sinus. 232 and 237 slices of $0.1-\mathrm{mm}$-thick of the transverse section of PPF and 56 and 58 figures of 0.6-mm-thick on multislice spiral CT were obtained respectively from two cranial specimens of adult cadaver. Now, one case was selected and was divided into the greater palatine canal portion and the PPF portion (the infrapterygopalatine fossa portion, pterygopalatine ganglionic one, suprapterygopalatine fossa one and the roof of PPF) and each portion was described, respectively.

i. The palatine greater canal portion: The slice appeared from the hard palate to the pterygomaxillary fissure. There were 114 images of thin transverse section and 27 figures of multislice spiral CT in this portion. Here the PPF communicated downwards with the greater and lesser palatine canals. The former was located anteriorly, whereas only one of the latter posteriorly. Greater and lesser palatine arteries were seen in the canals, but the palatine nerve could not be found.

ii. The infrapterygopalatine portion: It was the beginning layer of the PPF. The slice started at the pterygomaxillary fissure and ended at the layer of the beginning of the pterygopalatine ganglion. There were 44 images of transverse section and 10 figures of multislice spiral CT in this portion. PPF was elongated cleft in shape. Its anterior boundary was the posterior wall of the maxillary sinus, its medial boundary the perpendicular lamina of the palatine bone, posterior one the root of the pterygoid process. Laterally, it communicated with infratemporal fossa via pterygomaxillary fissure, through which the maxillary artery entered in the PPF. The posterior superior alveolar artery and infraorbital artery could be seen in this portion.

iii. The pterygopalatine ganglionic portion: There were 17 images of the transverse section and 5 figures of multislice spiral CT in this portion from the appearance of the pterygopalatine ganglion to the disappearance of it. The shape of PPF gradually evolved from oblong to an approximate equilateral triangle. Its structural character was the appearance of the pterygopalatine ganglion. The dimension of it was $3.91 \times 1.92 \mathrm{~mm}$ at the best layer. The shape of pterygopalatine ganglion was like a broad bean. It was clearly located at the posteromedial side of the PPF. Its longitudinal axis was an angle of $24.5 \mathrm{o}$ to the transverse axis of the body. The sphenopalatine artery could be seen in front of the ganglion, the infraorbital artery could be seen lateral to the ganglion. The boundary of PPF did not change.

iv. The suprapterygopalatine fossa portion: There were 44 images of the thin transverse section and 10 figures of multislice Spiral CT in this portion 
from the level of the disappearance of the pterygopalatine ganglion to the disappearance of the foramen rotundum. It was the key portion to research. The display of the medialward and backward communicating structure of the PPF was very well. On the medial side, the sphenopalatine foramen and artery could be shown between the orbital and sphenoidal processes of the perpendicular plate of the palatine bone. On the posterior side, the palatovaginal canal and artery, the pterygoid canal and artery, the foramen rotundum and maxillary nerve could be shown from medioinferior to superolateral. The vomerovaginal canal and artery were situated at the medial side and slightly superior position of the palatovaginal canal. The palatovaginal canal formed by the sphenoidal process of the perpendicular plate of the palatine bone and the vaginal process of the sphenoid bone, and the vomerovaginal canal formed by the vaginal process of the sphenoid bone and ala vomeris all could be shown very clearly. The anterior openings of the palatovaginal canal and vomerovaginal canal were located at the medial side of the posterior wall of the PPF, the posterior openings opened in the nasopharyngeal part. The boundary of PPF did not change, but the PPF presented an acidotus triangleshape structure that opened toward the posterior and medial sides because of the appearance of the openings.

v. The roof of PPF: There were 13 images of the thin transverse section and 4 figures of the multislice spiral CT in this portion from the disappearance of the foramen rotundum to the disappearance of the roof of PPF. Its shape was a long strip. In the two cases which were studied, the obvious characteristic of this portion was that $100 \%$ of the posterior wall of the posterior group of the ethmoidal sinuses was shown at the medial side of the anterior boundary and laterally, it was the posterior wall of the maxillary sinus. The roof was the inferior wall of the sphenoidal sinus. The perpendicular plate of the palatine bone was located at the medial side of this portion. The lateral side of the PPF communicated with the orbital apex via infraorbital fissure. The main structure in this portion was fatty and connective tissues. Now, six groups of the characteristic plane of thin transverse sectional images that matched with the multislice spiral CT were selected. PPF and its communicating structure were elucidated.
1. Image of the thin transverse section and the multislice spiral CT through pterygopalatine ganglion (Figure 1A,B)
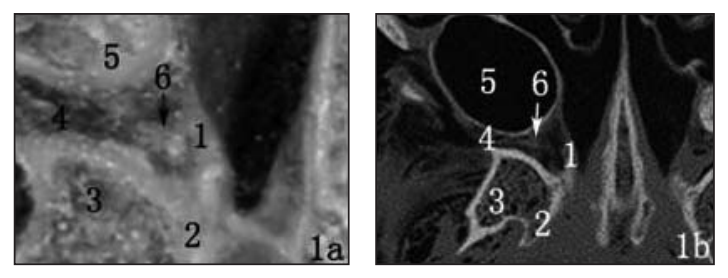

Figure 1A,B

The labeling structure at this section was pterygopalatine ganglion. PPF was an approximate equilateral triangle, its dimension being $8 \times 4 \mathrm{~mm}$. Its anterior boundary was the posterior wall of the maxillary sinus, its medial boundary the perpendicular plate of the palatine bone, posterior boundary was the anterior wall of the root of the medial and lateral pterygoid plates, its lateral boundary passed through the infratemporal fossa via pterygomaxillary fissure. The sphenopalatine foramen, foramen rotundum, pterygoid canal, palatovaginal canal and the vomerovaginal canal did not appear yet. The shape of the pterygopalatine ganglion was like a broad bean, and was located clearly at the posteromedial side of the PPF, dimension being $3.91 \times 1.92 \mathrm{~mm}$, the angle between the ganglion and the transverse axis was $24.5 \mathrm{o}$. The sphenopalatine artery could be seen in front of the ganglion, and the infraorbital artery could be seen at the lateral side.

2. Image of the thin transverse section and the multislice spiral CT through the anterior opening of the pterygoid canal. (Figure 2A,B)
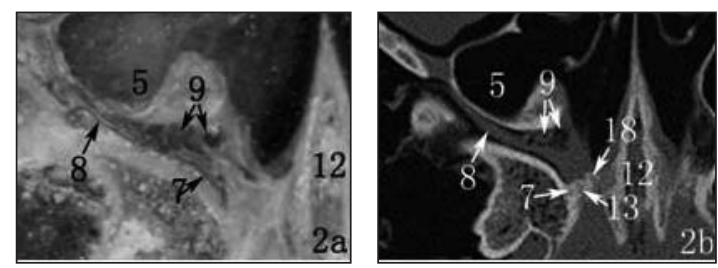

Figure $2 A, B$

The labeling structure at this section was the pterygoid artery and the anterior opening of the pterygoid canal. PPF at this section was a flat triangle shape, dimension being $8.75 \times 3.75 \mathrm{~mm}$, the boundary was same as the mentioned above. The maxillary nerve was seen very clearly, the length of this segment $11 \mathrm{~mm}$, the diameter $0.375 \mathrm{~mm}$. The maxillary nerve went out from the infraorbital foramen through the pterygomaxillary fissure, 
infraorbital fissue, groove and canal. The inferior wall of the anterior opening of the pterygoid canal appeared firstly. It was shown clearly that the starting portion of the pterygoid canal artery entered in the canal. The largest diameter at the anterior opening of the pterygoid canal was $3.25 \mathrm{~mm}$. The largest diameter of the pterygoid artery was 0.75 $\mathrm{mm}$. The sphenopalatine artery could be seen at the mediosuperior side of the inferior wall of the sphenopalatine foramen, the sphenopalatine foramen was seen at the laterosuperior side. The anterior openings of the palatovaginal canal and the vomerovaginal canal could appear firstly here and aligned at the medial side of the pterygoid canal in turn. The foramen rotundum did not appear but the pterygopalatine ganglion disappeared.

3. Image of thin transverse section and multislice spiral CT through palatovaginal canal (Figure 3A,B)
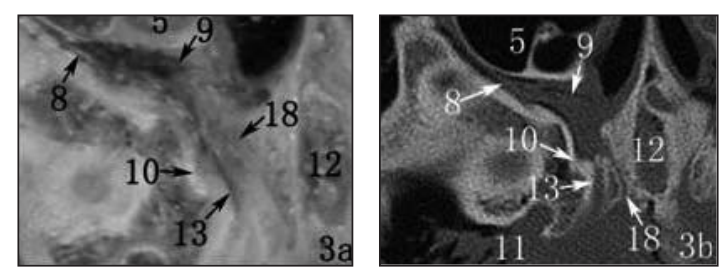

Figure $3 A, B$

The labeling structure on this section was the palatovaginal canal and artery. PPF presented an acidotus triangle which elongated toward the posteromedial side because the openings of the pterygoid canal, palatovaginal canal and vomerovaginal canal opened at the medial portion of the posterior wall of PPF, its dimension being 8.75 $x 4.0 \mathrm{~mm}$. The anterior wall was the posterior wall of the maxillary sinus, the medial wall the perpendicular plate of the palatine bone, the inferior wall of sphenopalatine foramen appeared first time at the medial wall. The sphenopalatine foramen and artery could be exposed. The lateral wall of this section communicated with the infratemporal fossa through pterygomaxillar fissure. The display of the maxillary nerve was the same as figures $2 \mathrm{~A}$ and $2 \mathrm{~B}$. The posterior wall was the anterior wall of the root portion of the medial and lateral pterygoid palates. There were openings of the vomerovaginal canal, palatovaginal canal and pterygoid canal from the medial side to the lateral side at the medial portion of the posterior boundary. The palatovaginal canal and artery could be clearly shown and were situated at the medial side running to the posteromedial side. The largest diameter of the canal at the anterior opening and the middle segment were 2.25 and 2.0 $\mathrm{mm}$, respectively. The diameter of the palatovaginal canal artery was $0.68 \mathrm{~mm}$. Its middle segment ran slightly towards posterolateral direction and opened at the upper portion of the nasopharyngeal portion. The vomerovaginal canal ran slightly towards posteromedial direction and opened at the upper portion of the nasopharyngeal portion. The posterior opening of the pterygoid canal appeared, and was located at the lower portion of the foramen lacerum. The inferior wall of the anterior portion of the C5 segment of the internal carotid artery did not appear yet.

4. Image of the thin transverse section and the multislice spiral CT through the sphenopalatine foramen (Figure 4A,B)
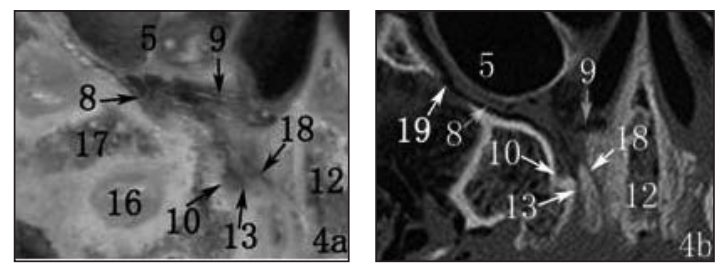

Figure $4 A, B$

The labeling structure at this section was the sphenopalatine foramen and artery, the vomerovaginal canal and artery. The PPF presented a triangle which opened towards the posteromedial direction because the sphenopalatine foramen, pterygoid canal and vomerovaginal canal opened in the PPF. Its dimension was $8.5 \times 3.5 \mathrm{~mm}$. The anterior boundary of PPF was the posterior wall of the maxillary sinus. Laterally, PPF at this section passed to the infratemporal fossa through the pterygomaxillary fissure. The display of the maxillary nerve was the same as the Figure 2A and 2B. The sphenopalatine foramen was shown at the medial wall, the anterior and posterior sides of the sphenopalatine foramen were formed by the orbital and sphenoidal processes of the perpendicular plate of the palatine bone, the sphenopalatine artery passed through this foramen. The largest anterior and posterior diameter was $3.9 \mathrm{~mm}$ and the diameter of the sphenopalatine artery was $1 \mathrm{~mm}$. The posterior boundary at this section was the anterior wall of the root of the pterygoid process. On its medial portion of the posterior boundary from the medial to the lateral there were openings of the vomerovaginal canal, palatovaginal canal and the pterygoid canal. The most prominent feature at this 
section was that the palatovaginal canal, palatovaginal artery and the vomerovaginal canal, vomerovaginal canal artery all could be clearly displayed.

5. Image of the thin transverse section and multislice spiral CT through the foramen rotundum (Figure 5A,B)
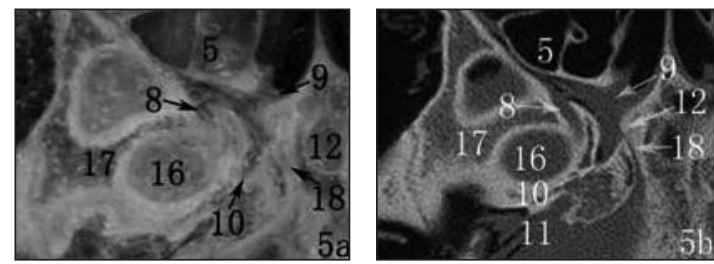

Figure $5 A, B$

The labeling structure at this section was foramen rotundum and the maxillary nerve. PPF gradually grown down and presented an open triangle structure towards the posteromedial direction., its dimension being $8.25 \times 2.75 \mathrm{~mm}$. The anterior boundary at this section was the posterior wall of the maxillary sinus. Laterally, this section of PPF communicated with the infratemporal fossa via pterygomaxillary fissure. Medially, the sphenopalatine foramen was located near the superior wall of the body of the sphenoid bone. Here the main trunk of the sphenopalatine artery had disappeared and merely a small branch could be seen. At the posterior boundary of this section, the anterior wall of the root of the pterygoid process was at the medial side. Behind it, the pterygoid canal, vomerovaginal canal and vomerovaginal canal artery could be seen, but the palatovaginal canal has disappeared. The most obvious characteristic at this section was that the foramen rotundum on the greater wing of the sphenoid bone and the maxillary nerve appeared at the lateral side of the posterior boundary. The largest diameters of both were 2.5 $\mathrm{mm}$ and $0.75 \mathrm{~mm}$, respectively. The vomerovaginal canal and artery were even more clearly. The largest diameter of the artery reached $0.7 \mathrm{~mm}$. The posterior opening of the pterygoid canal was even more obvious, and the whole course of this canal almost could be displayed. The inferior wall of the anterior portion of the C5 segment of the internal carotid artery did not appear at the lower portion of the foramen lacerum. The arrangement from lateral to medial sides was foramen rotundum, pterygoid canal and vomerovaginal canal in turn, but the palatovaginal canal has disappeared.
6. Image of the thin transverse section and multislice spiral CT through the roof of the pterygopalatine fossa (Figure 6A,B).
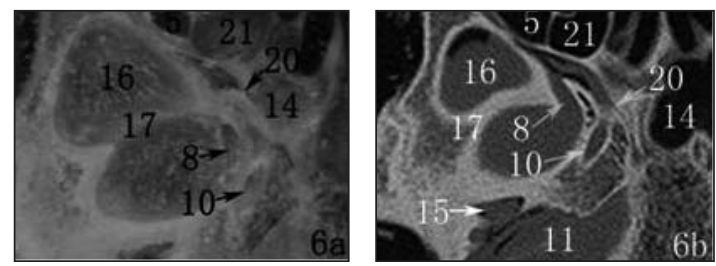

Figure $6 A, B$

The labeling structure at this section was that the posterior wall of the posterior group of the ethmoidal sinus constituted the bulk of the anterior wall of PPF. PPF was even smaller and displayed a flat triangle, its dimension being $6.75 \times 2.25 \mathrm{~mm}$. The maxillary sinus became smaller and its posterior wall merely constituted a small portion of the anterior wall of PPF, whereas the bulk of the anterior wall was constituted by the posterior wall of the posterior group of the ethmoidal sinus. Laterally, PPF at this section ran to the infratemporal fossa through the pterygomaxillary fissure. On the medial boundary, the sphenopalatine foramen would disappear soon near the superior wall of the body of the sphenoid bone. On the posterior boundary, the posterior opening of foramen rotundum and the maxillary nerve could be seen. The middle segment of the pterygoid canal could be seen at the posteromedial side of the root of the pterygoid process, its largest diameter being $2.25 \mathrm{~mm}$. The vomerovaginal canal would disappear soon, only the anterior opening of this could be seen.

\section{DISCUSSION}

The anterior boundary of PPF was the posterior wall of the maxillary sinus, the medial boundary: the perpendicular plate of the palatine bone, the posterior one: the root of the pterygoid process, the roof: the inferior wall of the sphenoidal sinus. The communicating structure of PPF has nine: it communicated anterosuperiorly with the orbital apex through infraorbital fissure, ran posterosuperiorly to the middle cranial fossa via foramen rotundum, went out inferiorly from the greater and lesser palatine foramina to approach the oral cavity via the greater and lesser palatine canals, passed medially to the upper part of the nasal cavity via the sphenopalatine foramen, communicated laterally with infratemporal fossa through pterygomaxillary fissure, communicated posteriorly 
to the foramen lacerum via the pterygoid canal, and entered posterormedially in the nasopharyngeal part via palatovaginal canal and vomerovaginal canal. The palatovaginal canal was formed by the sphenoidal process of the perpendicular plate of the palatine bone and the vaginal process of the sphenoid bone. The vomerovaginal canal was formed by the vaginal process of the sphenoid bone and the ala of the vomer. The principal content of the PPF was the maxillary artery and its branches and the accompanying vein, maxillary nerve and its branches, pterygopalatine ganglion and fatty, connective tissue and so on. The space of PPF was very narrow and small with complicated structures. The communication around PPF was very wide and content in PPF was very multiple. The clinical significance was important. PPF was divided into five portions according to the characteristic studied result combined with literatures and data: the greater palatine canal portion, the infrapterygopalatine fossa portion, pterygopalatine ganglionic portion, supra-pterygopalatine fossa portion, and the portion of the roof of PPF. The five portions were discussed respectively.

1. The portion of the greater palatine canal: This portion has important significance for the maxillofacial surgery, especially for the anesthesia of the greater palatine foramen. Methathrathip, D. et al [9] have performed detailed research on the greater palatine canal. The greater palatine canal could be clearly shown in the anterior aspect in 114 images of continuous thin transverse section and 27 figures of multislice spiral $\mathrm{CT}$, only one lesser palatine canal was shown in behind of the greater palatine canal in these images. The greater and lesser palatine arteries could be seen in the greater and lesser palatine canals. The palatine nerve could not be shown because the resolution rate of tissue was not enough. The greater palatine canal opened in the greater palatine foramen formed by the perpendicular plate of the palatine bone and the palatine process of the maxillary bone. The lesser palatine canal opened in the lesser palatine foramen which was located on the pyramidal process at the junction portion of the perpendicular plate and the horizontal plate of the palatine bone. PPF communicated with the oral cavity via these canals and foramina.

2. Infra-PPF portion: The structure on this portion was relatively simple. PPF communicated with infratemporal fossa through pterygomaxillary fissure, through which the maxillary artery entered in PPF. The demarcation between infra-PPF and the greater palatine canal could be differentiated by the pterygomaxillary fissue and pterygomaxillary suture, It had definite guiding significance for the diagnosis of image.

3. Pterygopalatine ganglionic portion: On the images of the continuous thin transverse section and multislice spiral $\mathrm{CT}$, three sides of the pterygopalatine ganglion $(75 \%)$ were shown in four sides ( 2 cases). The ganglion was located at the posteromedial side of PPF. Our result extremely resembled the report of Rumboldt $Z$ et al (8). In their report, PPF was divided into, anterior and posterior, two portions. The maxillary artery and its branches were the principal content in the anterior portion, and the pterygopalatine ganglion was the main content in the posterior portion. But our result was not same as Luo Junsheng and others' report that the pterygopalatine ganglion was located at the anterior side of the pterygoid canal and foramen rotundum. The reason was that there was an angle between the superior orbitomeatal line used for the thin transverse section and the horizontal line. The dimension of the ganglion was $3.91 \times 1.92 \mathrm{~mm}$. The dimension was same as the data reported by Luo Junsheng [7] and De Oliveira SH and others. The thin transverse section research on the location, morphology and dimension of pterygopalatine ganglion had important guiding significance for recognizing MRI and multislice spiral CT. MRI and multislice spiral CT could differentiate the suprapterygopalatine and infra-pterygopalatine portion through identifying pterygopalatine ganglion from its level of appearance to its level of disappearance.

4. Supra-pterygopalatine portion: This portion was the key portion for our research. On the images of the continuous thin transverse section and the multislice spiral CT, the sphenopalatine foramen and the sphenopalatine artery on the medial wall of the $\mathrm{PPF}$, the foramen rotundum and maxillary nerve, pterygoid canal and pterygoid canal artery, palatovaginal canal and palatovaginal canal artery, vomerovaginal canal and vomerovaginal canal artery on the posterior wall of PPF could be clearly shown. The spatial positioning relation of four canals on the posterior wall was: the pterygoid canal at the center, the foramen rotundum at the laterosuperior 
side, palatovaginal canal at the medioinferior side, the vomerovaginal canal at the slight mediosuperior side of the palatovaginal canal. PPF was a triangular structure which opened wide posteromedially because the sphenopalatine foramen, pterygoid canal, palatovaginal canal and vomerovaginal canal opened in PPF. The dimension of PPF was approximately $8.5 \times 3.5 \mathrm{~mm}$. The anterior boundary was the posterior wall of the maxillary sinus, lateral boundary communicated infratemporal fossa through pterygomaxillary fissure, medially, the sphenopalatine foramen could be exposed. The anterior and posterior sides of the sphenopalatine foramen were the orbital process and sphenoidal process of the perpendicular plate of the palatine bone. The sphenopalatine artery pierced the sphenopalatine foramen. The largest anterior and posterior diameters were $3.9 \mathrm{~mm}$. The diameter of the sphenopalatine artery was $1 \mathrm{~mm}$. The posterior boundary was the anterior wall of the root of the pterygoid process. The openings of the vomerovaginal canal, palatovaginal canal and pterygoid canal were located at its medial portion of the posterior boundary from medial to lateral. Researches on the communicating structure of PPF-sphenopalatine foramen and pterygoid canal made by scholars at home and abroad were very many, display of the imaging of the sphenopalatine foramen and pterygoid canal was comparatively easier, but the researches on the palatovaginal canal and vomerovaginal canal were very rarely. Only Rumboldt $\mathrm{Z}$ has made an imaging research on the palatovaginal canal and Lang $\mathrm{J}$ and others have reported researches on the vomerovaginal canal and palatovaginal canal (5). The imaging display of the vomerovaginal canal has not been reported at home and abroad till now. The nomenclature of the artery in the vomerovaginal canal has not been found and we therefore temporarily called it the vomerovaginal canal artery.
5. Roof of PPF: This portion was continuous with the supra- pterygopalatine fossa, and communicated with the orbital apex through infraorbital fissue. Whether this portion could be named as a migrating portion was value to explore and discuss. We found that a prominent characteristic at this portion was its anterior boundary-----the posterior wall of the maxillary sinus was just formed the lateral portion of the anterior wall of the PPF, and the medial portion of the anterior wall was formed by the posterior wall of the posterior group of the ethmoidal sinus. It was worthy to notice for the scholar of image.

\section{ACKNOWLEDGEMENT}

This research was supported by Natural Science Foundation of Zhejiang Province (No.Y2090376) and a grant from Zhejiang S\&T Bureau (No.2009C33111).

\section{REFERENCES}

1. De Oliveira SH, Freire Cda S, Costa WS, and Mandarim-deLacerda CA: Anatomic and quantitative study of the human pterygopalatine ganglion. Morphometry and stereology. Arq Neuropsiquiatr 51: 223-226, 1993

2. Erdogan N, Unur E, and Baykara M: CT anatomy of pterygopalatine fossa and its communications: a pictorial review. Comput Med Imaging Graph 27: 481-487, 2003

3. Gray H, Standring S, Ellis H, and Berkovitz BKB: Gray's anatomy: the anatomical basis of clinical practice. Edinburgh ; New York: Elsevier Churchill Livingstone, 2005: xx, 1627

4. Lang J: Skull base and related structures: Atlas of clinical anatomy. Stuttgart, New York: Schattauer, 1995: x, 326

5. Methathrathip D, Apinhasmit W, Chompoopong S, Lertsirithong A, Ariyawatkul T, and Sangvichien S: Anatomy of greater palatine foramen and canal and pterygopalatine fossa in Thais: Considerations for maxillary nerve block. Surg Radiol Anat 27: 511-516, 2005

6. Rumboldt Z, Castillo M, Smith JK: The palatovaginal canal: Can it be identified on routine CT and MR imaging? AJR Am J Roentgenol 179: 267-272, 2002

7. Zhang CW, Luo JC, and Yu Q: CT manifestation of pterygopalatine fossa in adult skull. Shanghai Kou Qiang Yi Xue 9: 135-137, 2000 